\title{
Association between Polymorphisms in Bitter Taste Receptor Genes and Clinical Features in Korean Asthmatics
}

\author{
Sun-Young Yoon ${ }^{a, c}$ Eun-Soon Shin ${ }^{b}$ So Young Park ${ }^{a}$ Sujeong Kim ${ }^{a}$ \\ Hyouk-Soo Kwon $^{\text {a }}$ You Sook Cho ${ }^{\text {a Hee-Bom Moon }}{ }^{\text {a }}$ Tae-Bum Kim ${ }^{\text {a }}$ \\ ${ }^{a}$ Division of Allergy and Clinical Immunology, Department of Internal Medicine, Asan Medical Center, University \\ of Ulsan College of Medicine, b DNA Link, Inc., and ' Division of Allergy and Pulmonology, Department of Internal \\ Medicine, Konkuk University Chungju Hospital, Seoul, Korea
}

\section{Key Words}

Bitter taste receptor - Asthma - Single nucleotide polymorphism

\begin{abstract}
Background: Bitter taste receptors (TAS2R) in human airway smooth muscle have recently been shown to have an important role in bronchodilation, together with $\beta_{2}$-adrenergic receptors. Object: To evaluate the association between genetic variations in TAS2R and clinical features, including bronchodilator response and asthma control. Method: We analyzed the association between single nucleotide polymorphisms (SNPs) of TAS2R10 and TAS2R14 and variables such as demographic data, atopy, duration of disease, and asthma control status, including variables such as asthma control test $(A C T)$ score, percent predicted value of forced expiratory volume in $1 \mathrm{~s}\left(\mathrm{FEV}_{1}\right)$, forced vital capacity (FVC), and $\mathrm{FEV}_{1} / \mathrm{FVC}$ ratio, as well as bronchodilator response (BDR), in 721 asthma patients in Korea. Result: Three novel SNPs of 633G $>A, 645 C>A$, and $-79 G>A$ in TAS2R10 and 3 known SNPs of $-815 \mathrm{~T}>\mathrm{C},-1267 \mathrm{G}>\mathrm{A}$, and $-1897 \mathrm{~T}>\mathrm{C}$ in TAS2R14 were analyzed. Increased BDR was significantly associated with SNPs of $-815 \mathrm{~T}>\mathrm{C}$ [OR $(95 \% \mathrm{Cl})=1.88(1.01-3.49), \mathrm{p}=0.04$ ] [J Gen Physiol 2005;125:535-553; Am J Respir Cell Mol Biol 2010;42:
\end{abstract}

$373-3812],-1267 \mathrm{~A}>\mathrm{G}$ [OR $(95 \% \mathrm{Cl})=2.07(1.03-4.15), \mathrm{p}=$ $0.04]$ and $-1897 \mathrm{~T}>\mathrm{C}[\mathrm{OR}(95 \% \mathrm{Cl})=3.05(1.01-9.23), \mathrm{p}=0.04$, in a dominant model, and $O R=1.91(1.08-3.36), p=0.02$, in a codominant model] of the TAS2R14 gene. There was a significant association between $-815 \mathrm{~T}>\mathrm{C}$ and a low mean ACT score [OR $(95 \% \mathrm{Cl})=5.84$ (1.94-17.61), $p=0.001]$. In haplotype analysis, TAC, CAT, and TGT, or TG and CA haplotypes on TAS2R14 were significantly associated with increased BDR; CAT and CA haplotypes were significantly associated with a low ACT score. Conclusion: Genetic variations in TAS2Rs may be valuable genetic markers to predict therapeutic response and outcomes in asthma. Further research in an independent cohort is needed. @ 2016 S. Karger AG, Basel

\section{Introduction}

Asthma is a chronic inflammatory disorder characterized by variable airflow obstruction and hyperresponsiveness of bronchi to different stimuli [1-3]. Most asthma types can be well controlled by current asthma medication, including inhaled corticosteroid with or without long-acting $\beta_{2}$-agonists, leukotriene antagonists, theophylline, tiotropium, and even omalizumab; however, approximate-

\section{KARGER}

E-Mail karger@karger.com

www.karger.com/res (c) 2016 S. Karger AG, Basel

0025-7931/16/0912-0141\$39.50/0
Tae-Bum Kim, MD, PhD

Division of Allergy and Clinical Immunology Department of Internal Medicine, Asan Medical Center

University of Ulsan College of Medicine, 88, Olympic-ro 43-gil

Songpa-gu, Seoul 138-736 (Korea), E-Mail allergy@ medimail.co.kr 
ly $5-10 \%$ of all patients fail to achieve control despite the availability of optimal asthma treatments [4], leading to a great burden on health costs [5]. Thus, there is an urgent need for new treatment approaches for asthma.

Bronchodilators are a very important asthma treatment modality that directly reverses airway obstruction [6], although inhaled corticosteroids are the mainstay of asthma treatment. Recently, it has become apparent that bronchoconstriction without additional inflammation induces airway remodeling in patients with asthma [7].

$G$ protein-coupled receptors are known to regulate major signaling pathways in the airways that control bronchial relaxation and contraction [8]. Bitter taste receptors (TAS2Rs) are members of the G protein-coupled receptor family and have recently been discovered in airway epithelium and smooth muscle cells [9]. Bitter agonist-induced airway relaxation has been documented in animal studies $[10,11]$, and researches with human airway tissues also showed concordant results, although there is a difference in the magnitude of airway relaxation [9, 12-14]. Among subtypes of TAS2Rs, TAS2R5, 10, and 14 are considered to have a prime role in bronchodilation [15].

The exact signaling pathways of TAS2R-mediated relaxation are still unclear. Several explanations such as membrane hyperpolarization by the activation of large conductance calcium-activated potassium $\left(\mathrm{K}_{\mathrm{Ca}}\right)$ channels, inhibition of L-type voltage-dependent calcium channels and inhibition of phosphatidylinositol-3-kinases are reported, although none of these pathways could fully explain the mechanism of TAS2R-induced bronchodilation $[9,12,14]$. However, these results imply the possibility that TAS2Rs are involved in airway relaxation via a different path than $\beta_{2}$-adrenergic receptors ( $\left.\beta_{2} \mathrm{ARs}\right)$, which increase intracellular cAMP leading to the activation of protein kinase A $[8,16]$. Therefore, TAS2R agonists could be potent novel therapeutic agents for asthma.

Inhaled $\beta_{2}$-agonists are the mainstay of asthma treatment and showed a heterogeneous response in individuals with asthma [17-19]. Genetic variation in the $\beta_{2} A R$ genes might be partly involved in these phenomena, and the number of studies have shown the relationship between various $\beta_{2} A R$ polymorphisms and the degree of responsiveness or desensitization to the $\beta_{2}$-agonists and asthma severity [20-23].

Based on these results, we hypothesized that TAS2R polymorphisms may affect various clinical characteristics of asthma, just as genetic variations in $\beta_{2} A R s[24,25]$. The aim of this study was to evaluate the association between $T A S 2 R$ polymorphisms and the response to bronchodilator and asthma control status in asthmatic patients.

\section{Methods}

\section{Subjects and Study Design}

The study subjects were recruited from the COREA (Cohort for Reality and Evolution of Adult Asthma in Korea) cohort. As described previously [26], the study participants were aged $\geq 14$ years, with at least one typical asthma symptom, such as chronic cough, dyspnea, sputum or wheezing, for more than 3 months. Asthma was diagnosed based on airway hyperresponsiveness, defined by the provocation concentration of methacholine $(\leq 16$ $\mathrm{mg} / \mathrm{ml}$ ) that caused a decrease in forced expiratory volume in $1 \mathrm{~s}\left(\mathrm{FEV}_{1}\right)$ of $20 \%$, or airway reversibility, defined as improvement in $\mathrm{FEV}_{1}$ of more than $200 \mathrm{ml}$ and $12 \%$ of the percentage predicted after the administration of $180 \mu \mathrm{g}$ of albuterol by a metered-dose inhaler. This latter measure was used when the patients had a basal predicted $\mathrm{FEV}_{1}$ of less than $60 \%$. Subjects with destroyed lungs, bronchiectasis, or lung resection were excluded $[26,27]$.

A total of 721 subjects were eligible for genotyping. All study subjects were optimally managed according to the Global Initiative for Asthma (GINA) guidelines [3]. Demographic data, total immunoglobulin (Ig) E, results of the skin prick test, peripheral blood and sputum eosinophil counts at the time of enrolment into the COREA were obtained. Spirometric measurement, including pre- and postbronchodilator $\mathrm{FEV}_{1}$, forced vital capacity (FVC) values, $\mathrm{FEV}_{1} /$ FVC ratio and positivity of the bronchodilator response (BDR) test [28] at enrolment were recorded. If data from follow-up visits were available, we also recorded pulmonary function (prebronchodilator $\mathrm{FEV}_{1}, \mathrm{FVC}$ values and $\mathrm{FEV}_{1} / \mathrm{FVC}$ ratio) and Asthma Control Test (ACT) [29] score at 3 and 6 months after enrolment.

To measure the improvement of asthma control and pulmonary function after enrolment, we defined new variables: mean ACT score at 6 months; ACT variability during the 6-month period after enrolment; difficulty in treating asthma at 6 months, and $\mathrm{FEV}_{1}$ improvement at 6 months. The mean ACT score during the 6-month period was the average of ACT scores at 3 and 6 months. Based on previous research which reported that ACT scores $\leq 19$ indicate uncontrolled asthma, we divided the study subjects into two groups: the low mean ACT group (mean ACT score $\leq 19$ ) and the high ACT group (mean ACT score $>19$ ) [3032]. Variability in the ACT score was defined as the difference between ACT scores at 3 and 6 months. Study subjects were divided into two groups based on this value: ACT variability $\geq 4$ versus $<4$

Patients who did not achieve an acceptable level of control at step 4 (using a reliever plus $\geq 2$ controllers) treatment 6 months after enrolment were regarded as having difficult-to-treat asthma, according to the GINA guidelines [3]. When the best prebronchodilator $\mathrm{FEV}_{1}$ at 6 months after enrolment was compared with baseline $\mathrm{FEV}_{1}$, patients who showed no increase in prebronchodilator $\mathrm{FEV}_{1}$ of $>200 \mathrm{ml}$ and $12 \%$ were classified into the poor $\mathrm{FEV}_{1}$ improvement group. To compare genetic variation status, we also included 337 nonasthmatic subjects, who agreed to participate in this study, from another cohort which is consistent with chronic idiopathic urticaria (CIU) patients in our center. All of these control subjects were excluded from the asthma patient group through an interview regarding their clinical symptoms.

All study subjects were fully informed of the aim of this study before enrolment, and informed consent was obtained from each 
participant. If study subjects were children, written informed consent was obtained from their parents. The study protocols were approved by the Internal Review Board and Ethics Committee of Asan Medical Center. This study was performed in 2012.

Genotyping and Selection of Single Nucleotide Polymorphisms

DNA was extracted from blood samples collected in ethylenediaminetetraacetic acid using the Wizard Genomic DNA Purification Kit (Promega Co., Madison, Wis., USA) according to the manufacturer's recommendation. After the entire sequencing of the TAS2R10 and TAS2R14 genes in 24 healthy controls, candidate single nucleotide polymorphisms (SNPs) were selected by the levels of the linkage disequilibrium (LD) statistic. Due to the low levels of $\mathrm{LD}\left(\mathrm{r}^{2}<0.001\right)$ among SNPs, 3 SNPs $(-79 \mathrm{G}>\mathrm{A}, 633 \mathrm{G}>\mathrm{A}$, and $645 \mathrm{C}>\mathrm{A}$ ) with a minor allele frequency (MAF) $\geq 1 \%$ were selected in the TAS2R10 gene. In case of TAS2R14, all polymorphisms with an MAF $\geq 5 \%$ were included, and we selected 3 SNPs $(-815 \mathrm{~T}>\mathrm{C},-1897 \mathrm{~T}>\mathrm{C}$, and $-1267 \mathrm{~A}>\mathrm{G})$ using the Tagger program within Haploview $\left(\mathrm{r}^{2}>0.8\right)$.

The TaqMan assay was performed according to the manufacturer's instructions (ABI, Foster City, Calif., USA). The SNaPshot assay was performed according to the manufacturer's instructions (ABI PRISM SNaPshot Multiplex kit, Foster City, Calif., USA). Analysis was carried out using the Genemapper software (version 4.0; Applied Biosystems, San Francisco, Calif., USA).

\section{Statistical Analysis}

SNPs and haplotypes were analyzed as 3 component variables (i.e., $\mathrm{AA}, \mathrm{AB}$, and $\mathrm{BB}$; $\mathrm{A}$ is the major frequency allele or haplotype and $\mathrm{B}$ is the minor frequency allele or haplotype). Haplotype analysis was conducted using the Haploview program (version 4.2). To determine whether the effect of any single homozygous genotype differed from the common effects of the heterozygous genotype or another homozygote (i.e., the dominant model, $\mathrm{AA}$ vs. $\mathrm{AB}+\mathrm{BB}$; the recessive model, $\mathrm{BB}$ vs. $\mathrm{AB}+\mathrm{AA}$, or the codominant model, $A A$ vs. $A B$ vs. $B B$ ), a $2 \times 2$ contingency table was created. The $\chi^{2}$ test for categorical variables and Student's t test or ANOVA with Scheffé's posttest for continuous variables were conducted. MannWhitney and Kruskal-Wallis tests were used as nonparametric methods. To determine the odds ratios (ORs) and 95\% confidence intervals (CIs), multiple logistic regression modelling was performed. All analyses were adjusted for age, gender and body mass index (BMI). Hardy-Weinberg equilibrium was analyzed using the permutation test. All statistical analyses were performed using SAS software (version 9.1.3, Cary, N.C., USA). p values $<0.05$ were regarded as significant.

\section{Results}

\section{Clinical Characteristics of Subjects}

Of the 721 patients, $304(42.2 \%)$ were male and the mean age was 54.5 years. Due to the availability of the blood sample volume, patients under the age of 19 years could not be included in the current study. More than half of the patients $(371,51.5 \%)$ were never-smokers. The average baseline prebronchodilator $\mathrm{FEV}_{1}$ was 2.18 liters
Table 1. Clinical characteristics of 721 asthma subjects

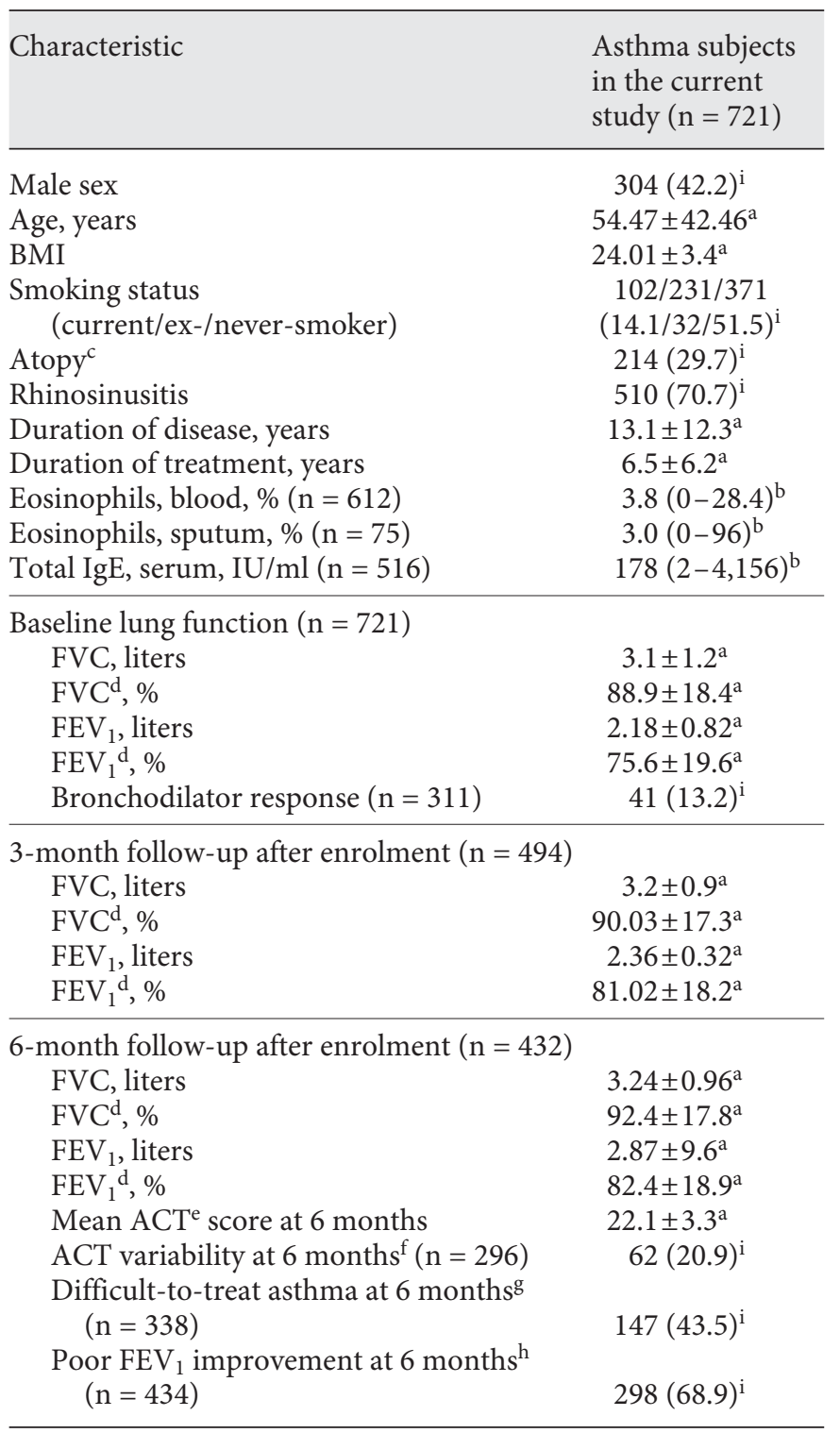

${ }^{\mathrm{a}}$ Mean $\pm \mathrm{SD} .{ }^{\mathrm{b}}$ Median (range). ${ }^{\mathrm{c}}$ Positive skin test response to one or more common allergens. ${ }^{d}$ Percentage predicted. ${ }^{\mathrm{e}}$ Total number and percentage of patients who showed positive bronchodilator response. ${ }^{\mathrm{f}}$ The difference between ACT scores at 3 and 6 months (shown as the number of subjects who showed $\geq 4$ ACT variability only). ${ }^{g}$ Patients who did not achieve control status at step 4 (reliever $+\geq 2$ controllers) treatment at 6 months after enrolment (shown as the number of subjects who did not achieve control status). ${ }^{\mathrm{h}}$ When the best prebronchodilator $\mathrm{FEV}_{1}$ during 6 months after enrolment was compared with baseline $\mathrm{FEV}_{1}$, patients whose prebronchodilator $\mathrm{FEV}_{1}$ increased by $<200 \mathrm{ml}$ and $12 \%$ were classified as poor $\mathrm{FEV}_{1}$ improvement group. ${ }^{\mathrm{i}}$ Number of patients $(\%)$. 
Table 2. Haplotype frequency in TAS2R10 and TAS2R14 genes

\begin{tabular}{lllll}
\hline TAS2R10 & 633G $>$ A & 645C $>$ A & $-79 \mathrm{G}>\mathrm{A}$ & Frequency, \% \\
\hline Ht1 & G & C & A & 96.8 \\
\hline TAS2R14 & -815 T $>$ C & $-1267 \mathrm{~A}>\mathrm{G}$ & $-1897 \mathrm{~T}>$ C & Frequency, \% \\
\hline Ht2 & T & A & C & 45.8 \\
Ht3 & C & A & T & 23.9 \\
Ht4 & T & G & T & 20.2 \\
Ht5 & T & G & C & 6.4 \\
Ht6 & T & A & & 49.7 \\
Ht7 & T & G & & 26.5 \\
Ht8 & C & A & & 23.8 \\
\hline
\end{tabular}

(75.6\% predicted), and the follow-up $\mathrm{FEV}_{1}$ values at 3 and 6 months were 2.36 liters (81.02\%) and 2.87 liters (82.4\%), respectively. The mean ACT score at 6 months was 22.1, and the number of patients showing poor $\mathrm{FEV}_{1}$ improvement at 6 months was 298 (68.9\%; table 1). Controls showed a similar gender distribution $(131,37.6 \%)$, but the mean age was lower than that of asthmatic patients ( 54.5 vs. 47.8 years, data not shown).

In the subgroup analysis, we compared the baseline characteristics depending on the ACT score (low ACT vs. high ACT group). Except for the lung function 3 and 6 months after enrolment, most of the baseline characteristics, including age, gender and laboratory findings, did not show any significant difference (online suppl. table 1; see www.karger.com/doi/10.1159/000443796 for all online suppl. material).

\section{SNP Identification in the TAS2R Genes}

Because the TAS2R10 and TAS2R14 subtypes are the most highly expressed in human airway smooth muscle [9], we sought to sequence these genes. After sequencing the TAS2R10 gene, 15 SNPs were identified. Of these, 3 SNPs (-79G $>$ A, 633G $>$ A, and 645C $>$ A) were newly discovered SNPs with a $>0.1 \%$ MAF. We selected all 3 SNPs as tagging SNPs by considering the level of LD (online suppl. table 2). Twenty-three SNPs were identified through sequencing of the TAS2R14 gene. Three of these SNPs $(-815 \mathrm{~T}>\mathrm{C},-1267 \mathrm{~A}>\mathrm{G}$, and $-1897 \mathrm{~T}>\mathrm{C})$ had $\mathrm{a}>10 \%$ MAF and were selected as tagging SNPs (online suppl. table 3). Eight haplotypes were reconstructed on both genes [TAS2R10: Ht1 (GCG); TAS2R14: Ht2 (TAC), Ht3 (CAT), Ht4 (TGT), Ht5 (TGC), Ht6 (TA), Ht7 (TG), Ht8 (CA); table 2].
Table 3. Frequency of TAS2R genotypes in asthmatic patients and healthy controls

\begin{tabular}{|c|c|c|c|}
\hline Genotype & $\begin{array}{l}\text { Controls } \\
(n=337)\end{array}$ & $\begin{array}{l}\text { Asthmatics } \\
(\mathrm{n}=721)\end{array}$ & $\mathrm{p}$ value \\
\hline \multicolumn{4}{|l|}{$-79 \mathrm{G}>\mathrm{A}$} \\
\hline GG & 335 (99.7\%) & 705 (99.3\%) & n.s. ${ }^{a}$ \\
\hline GA & $2(0.3 \%)$ & $5(0.7 \%)$ & \\
\hline AA & 0 & 0 & \\
\hline \multicolumn{4}{|l|}{$645 \mathrm{C}>\mathrm{A}$} \\
\hline CC & $331(98.2 \%)$ & $710(99 \%)$ & n.s. ${ }^{a}$ \\
\hline $\mathrm{CA}$ & $6(1.8 \%)$ & $7(1 \%)$ & \\
\hline AA & 0 & 0 & \\
\hline \multicolumn{4}{|l|}{$633 \mathrm{G}>\mathrm{A}$} \\
\hline GG & $322(95.8 \%)$ & $681(95.1 \%)$ & n.s. \\
\hline GA & $13(3.9 \%)$ & $35(4.9 \%)$ & \\
\hline $\mathrm{AA}$ & $1(0.3 \%)$ & 0 & \\
\hline \multicolumn{4}{|l|}{$-815 \mathrm{~T}>\mathrm{C}$} \\
\hline $\mathrm{TT}$ & $201(60.7 \%)$ & $414(57.7 \%)$ & n.s. \\
\hline $\mathrm{TC}$ & $112(33.8 \%)$ & $265(37 \%)$ & \\
\hline $\mathrm{CC}$ & $18(5.4 \%)$ & $38(5.3 \%)$ & \\
\hline \multicolumn{4}{|l|}{$-1267 A>G$} \\
\hline $\mathrm{AA}$ & $188(56 \%)$ & $395(55.2 \%)$ & n.s. \\
\hline $\mathrm{AG}$ & $124(36.9 \%)$ & $261(36.5 \%)$ & \\
\hline GG & $24(7.1 \%)$ & $59(8.3 \%)$ & \\
\hline \multicolumn{4}{|l|}{$-1897 \mathrm{~T}>\mathrm{C}$} \\
\hline CC & $98(29.2 \%)$ & 207 (29\%) & n.s. \\
\hline CT & $173(51.5 \%)$ & $330(46.2 \%)$ & \\
\hline $\mathrm{TT}$ & $65(19.3 \%)$ & $177(24.8 \%)$ & \\
\hline \multicolumn{4}{|l|}{ Haplotypes } \\
\hline Ht1 (GCG) & $335(99.4 \%)$ & 707 (98.1\%) & n.s. \\
\hline Ht2 (TAC) & $247(73.2 \%)$ & $489(67.8 \%)$ & $0.04^{\mathrm{b}}$ \\
\hline Ht3 (CAT) & $130(38.5 \%)$ & $301(41.7 \%)$ & n.s. \\
\hline Ht4 (TGT) & $119(35.3 \%)$ & $253(35.1 \%)$ & n.s. \\
\hline Ht5 (TGC) & $35(10.4 \%)$ & $86(11.9 \%)$ & n.s. \\
\hline Ht6 (TA) & $254(75.3 \%)$ & $521(72.2 \%)$ & n.s. \\
\hline Ht7 (TG) & $147(43.6)$ & $320(44.3 \%)$ & n.s. \\
\hline Ht8 (CA) & $130(38.5 \%)$ & $302(41.8 \%)$ & n.s. \\
\hline
\end{tabular}

n.s. $=$ Not significant. $-79 \mathrm{G}>\mathrm{A}, 645 \mathrm{C}>\mathrm{A}$, and $633 \mathrm{G}>\mathrm{A}$ were from TAS2R10; $-815 \mathrm{C}>\mathrm{T},-1267 \mathrm{~A}>\mathrm{G}$, and $-1897 \mathrm{~T}>\mathrm{C}$ were from TAS2R14. ${ }^{\mathrm{a}} \chi^{2}$ test, $\mathrm{p}>0.05 .{ }^{\mathrm{b}}$ Determined using a dominant model (TAC/TAC + TAC/others vs. others/others) and the $\chi^{2}$ test.

\section{Comparison of Genotype Frequency of TAS2R SNPs}

between Asthma Patients and Healthy Controls

When we compared the genotype frequency of TAS2R SNPs between 721 asthmatics and 337 nonasthmatic adult controls, there were no significant differences in the frequency of the 6 tagging SNPs $(-79 \mathrm{G}>\mathrm{A}, 633 \mathrm{G}>\mathrm{A}$, $645 \mathrm{C}>\mathrm{A},-815 \mathrm{~T}>\mathrm{C},-1267 \mathrm{~A}>\mathrm{G}$, and $-1897 \mathrm{~T}>\mathrm{C}$ ) between 
Table 4. Genetic effect of SNPs in TAS2R10 on airway reversibility and asthma control status

\begin{tabular}{|c|c|c|c|c|c|c|}
\hline & & BDR positive ${ }^{c}$ & $\begin{array}{l}\text { Mean ACT } \\
\text { score during } \\
6 \text { months }^{\mathrm{d}}\end{array}$ & $\begin{array}{l}\text { ACT variability } \\
\text { during } \\
6 \text { months }\end{array}$ & $\begin{array}{l}\text { Difficult-to-treat } \\
\text { asthma at } \\
6 \text { months }^{f}\end{array}$ & $\begin{array}{l}\text { Poor FEV } \\
\text { improvement at } \\
6 \text { months }^{g}\end{array}$ \\
\hline \multicolumn{7}{|l|}{$-79 \mathrm{G}>\mathrm{A}$} \\
\hline \multirow[t]{2}{*}{ Dominant $^{\mathrm{a}}$} & $\mathrm{p}$ value $\mathrm{e}^{\mathrm{b}}$ & 0.99 & 0.18 & 0.99 & 0.98 & 0.96 \\
\hline & OR $(95 \% \mathrm{CI})$ & 0 & $6.58(0.4,116.69)$ & 0 & 0 & $1.07(0.06,17.9)$ \\
\hline \multirow[t]{2}{*}{ Codominant $^{\mathrm{a}}$} & $\mathrm{p}$ value & 0.99 & 0.18 & 0.99 & 0.98 & 0.96 \\
\hline & OR $(95 \% \mathrm{CI})$ & 0 & $6.58(0.4,116.69)$ & 0 & 0 & $1.07(0.06,17.9)$ \\
\hline \multicolumn{7}{|l|}{$645 \mathrm{C}>\mathrm{A}$} \\
\hline \multirow{2}{*}{ Dominant } & $\mathrm{p}$ value & 0.45 & 0.98 & 0.72 & 0.21 & 0.91 \\
\hline & OR (95\% CI) & $2.17(0.21,32.42)$ & 0 & $1.5(0.15,15.16)$ & $3.89(0.4,37.78)$ & $1.14(0.09,13.35)$ \\
\hline \multicolumn{7}{|l|}{$633 \mathrm{G}>\mathrm{A}$} \\
\hline \multirow[t]{2}{*}{ Dominant } & $\mathrm{p}$ value & 0.97 & 0.97 & 0.79 & 0.78 & 0.68 \\
\hline & OR $(95 \% \mathrm{CI})$ & 0 & $1.02(0.21,4.97)$ & $1.2(0.31,4.71)$ & $1.15(0.43,3.06)$ & $1.27(0.4,3.98)$ \\
\hline Recessive & $\begin{array}{l}\text { p value } \\
\text { OR }(95 \% \mathrm{CI})\end{array}$ & n.a. & n.a. & n.a. & n.a. & n.a. \\
\hline \multirow[t]{2}{*}{ Codominant } & $\mathrm{p}$ value & 0.98 & 0.92 & 0.69 & 0.74 & 0.7 \\
\hline & OR $(95 \% \mathrm{CI})$ & 0 & $1.086(0.23,5.13)$ & $1.316(0.35,5.02)$ & $1.18(0.44,3.17)$ & $1.25(0.4,3.94)$ \\
\hline
\end{tabular}

n.a. $=$ Not assessed. ${ }^{\text {a }}$ Models of the minor allele (dominant: $\mathrm{AA}$ vs. $\mathrm{AB}+\mathrm{BB}$, recessive: $\mathrm{AA}+\mathrm{AB}$ vs. $\mathrm{BB}$, codominant: $\mathrm{AA}$ vs. $\mathrm{AB}$ vs. $\mathrm{BB}) .{ }^{\mathrm{b}} \mathrm{p}$ value from multiple logistic regression analysis after adjusting for age, gender and BMI. ${ }^{\mathrm{c}}$ Control (reference): negative BDR; case: positive BDR. ${ }^{\mathrm{d}}$ Control (reference): the average of ACT scores at 3 and 6 months $>19$; case: $\leq 19 .{ }^{\mathrm{e}}$ Control (reference): the difference between ACT scores at 3 and 6 months $\geq 4$; case: $<4 .{ }^{f}$ Control (reference): patients who achieved control status at step 4 (reliever $+\geq 2$ controllers) treatment at 6 months after enrolment; case: patients who did not achieve control status. ${ }^{\mathrm{g}}$ Control (reference): the increase in the best prebronchodilator $\mathrm{FEV}_{1}$ value during 6 months after enrolment $\geq 200 \mathrm{ml}$ and $12 \%$ predicted; case: $<200 \mathrm{ml}$ and $12 \%$ predicted.

the two groups. The only difference was with Ht2 (TAC), which had a significantly lower frequency in asthmatic patients in a dominant model (table 3 ).

Association between TAS2R SNPs and Haplotypes and Clinical Characteristics of Asthma

We first evaluated the association between genetic polymorphisms in TAS2R and baseline demographic and laboratory characteristics including the duration of disease, the duration of treatment, the proportion of positive skin prick tests, the total serum IgE level and sputum eosinophil counts. We found no significant associations between TAS2R SNPs and those parameters (online suppl. tables 4 and 5).

When we analyzed the relationship between genetic variations in the TAS2R gene and airway reversibility, we found no significant association between a positive BDR and TAS2R10 SNPs (table 4). However, a positive BDR was significantly associated with $-815 \mathrm{~T}>\mathrm{C}$ [OR $(95 \%$ $\mathrm{CI})=1.88(1.01-3.49), \mathrm{p}=0.04$, in a codominant model $]$, $-1267 \mathrm{~A}>\mathrm{G}$ [OR $(95 \% \mathrm{CI})=2.07(1.03-4.15), \mathrm{p}=0.04$, in a dominant model] and $-1897 \mathrm{~T}>\mathrm{C}[\mathrm{OR}(95 \% \mathrm{CI})=3.05$ $(1.01-9.23), \mathrm{p}=0.04$, in a dominant model and $\mathrm{OR}=1.91$ $(1.08-3.36), \mathrm{p}=0.02$, in a codominant model] in the TAS2R14 gene (table 5).

When we analyzed the relationship between genetic variations in the TAS2R gene and the mean ACT score during the 6-month period after enrolment, we found a significant association between $-815 \mathrm{~T}>\mathrm{C}$ in the TAS2R14 gene and a low mean ACT score [OR $(95 \% \mathrm{CI})=5.84$ (1.94-17.61), $\mathrm{p}=0.001$, in a recessive model; table 5]. However, there were no statistically significant associations between TAS2R SNPs and other variables, including ACT variability, difficult-to-treat asthma and poor $\mathrm{FEV}_{1}$ improvement during the 6-month follow-up (tables 4,5$)$. 
Table 5. Genetic effect of SNPs in TAS2R14 on airway reversibility and asthma control status

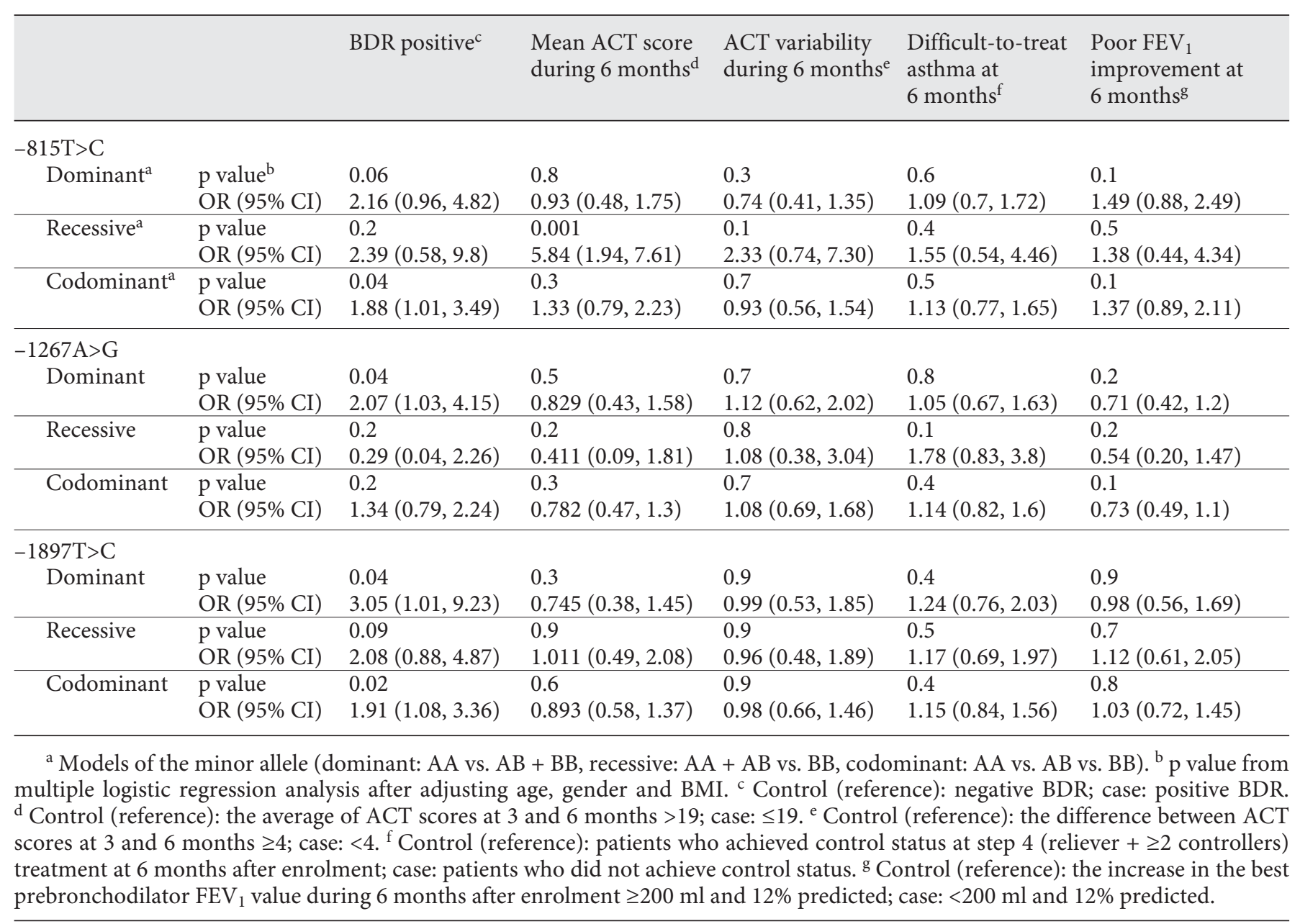

Haplotype analysis demonstrated that haplotypes $\mathrm{Ht} 3$ (CAT), Ht4 (TGT), Ht7 (TG) and Ht8 (CA) of TAS2R14 were significantly more common in patients with a positive BDR. By contrast, patients with Ht2 (TAC) and Ht6 (TA) of TAS2R14 had a reduced frequency of positive BDR. In addition, Ht3 (CAT) and Ht8 (CA) were significantly associated with a low mean ACT score during the 6 months after enrolment. We found no association between haplotypes of TAS2R and other variables (table 6).

The relationship between genetic variations of the $T A S 2 R$ gene and serial spirometry findings, including $\mathrm{FVC}$ and $\mathrm{FEV}_{1}$ at the time of enrolment and after 3 and 6 months, was also analyzed. FVC and $\mathrm{FEV}_{1}$ at 3 months were associated with $633 \mathrm{G}>\mathrm{A}$ in TAS2R10 (online suppl. table 6A, B).

\section{Discussion}

Bitter taste receptors are extensively expressed from the tongue to the intestinal mucosa and the pancreas [3335]. They protect against the ingestion of potentially toxic substances by producing nausea and vomiting or by interrupting gastric emptying, leading to a delayed delivery of the toxin to the gastrointestinal system $[36,37]$. In recent years, the expression of bitter taste receptors has been found in extraoral tissues, including respiratory epithelia [38] and airway smooth muscle cells [39]. A number of TAS2R subtypes were confirmed to be expressed in human bronchi and among them, TAS2R5, 10 and 14 are supposed to be mainly involved in the relaxation of these tissues. In the current study, we analyzed the genetic variation in TAS2R10 and 14 [15].

Although it was not as marked as initially reported by Deshpande et al. [9], several recent studies with human 
Table 6. Genetic effect of haplotypes in TAS2R on airway reversibility and asthma control status

\begin{tabular}{|c|c|c|c|c|c|c|}
\hline & & BDR positive ${ }^{c}$ & $\begin{array}{l}\text { Mean ACT score } \\
\text { during } 6 \text { months }\end{array}$ & $\begin{array}{l}\text { ACT variability } \\
\text { during } 6 \text { months }\end{array}$ & $\begin{array}{l}\text { Difficult-to-treat } \\
\text { asthma at } \\
6 \text { months }^{f}\end{array}$ & $\begin{array}{l}\text { Poor FEV }{ }_{1} \\
\text { improvement at } \\
6 \text { months }^{g}\end{array}$ \\
\hline \multicolumn{7}{|l|}{ Ht1 (GCG) } \\
\hline Dominant $\mathrm{t}^{\mathrm{a}}$ & $\begin{array}{l}\mathrm{p} \text { value }{ }^{\mathrm{b}} \\
\text { OR }(95 \% \mathrm{CI})\end{array}$ & n.a. & n.a. & n.a. & n.a. & n.a. \\
\hline \multirow[t]{2}{*}{ Codominant $^{\mathrm{a}}$} & $\mathrm{p}$ value & 0.5 & 0.9 & 0.8 & 0.8 & 0.6 \\
\hline & OR $(95 \% \mathrm{CI})$ & $1.98(0.24,15.75)$ & $0.94(0.25,3.46)$ & $0.89(0.27,2.89)$ & $0.93(0.39,2.23)$ & $0.81(0.3,2.17)$ \\
\hline \multicolumn{7}{|l|}{ Ht2 (TAC) } \\
\hline \multirow{2}{*}{ Dominant } & $\mathrm{p}$ value & 0.01 & 0.9 & 0.7 & 0.6 & 0.7 \\
\hline & OR $(95 \% \mathrm{CI})$ & $0.37(0.16,0.84)$ & $0.99(0.5,1.98)$ & $0.89(0.47,1.68)$ & $0.9(0.55,1.46)$ & $1.08(0.61,1.92)$ \\
\hline \multicolumn{7}{|l|}{ Ht3 (CAT) } \\
\hline \multirow{2}{*}{ Dominant } & $\mathrm{p}$ value & 0.06 & 0.8 & 0.3 & 0.7 & 0.1 \\
\hline & OR $(95 \% \mathrm{CI})$ & $2.13(0.95,4.78)$ & $0.92(0.48,1.74)$ & $0.73(0.41,1.34)$ & $1.07(0.68,1.67)$ & $1.46(0.87,2.46)$ \\
\hline \multirow[t]{2}{*}{ Recessive } & $\mathrm{p}$ value & 0.3 & $<0.001$ & 0.2 & 0.4 & 0.6 \\
\hline & OR $(95 \% \mathrm{CI})$ & $2.39(0.58,9.78)$ & $5.75(1.91,17.36)$ & $2.31(0.73,7.2)$ & $1.57(0.54,4.52)$ & $1.38(0.44,4.32)$ \\
\hline \multirow[t]{2}{*}{ Codominant } & $\mathrm{p}$ value & 0.04 & 0.2 & 0.7 & 0.5 & 0.2 \\
\hline & OR $(95 \%$ CI $)$ & $1.87(1.01,3.47)$ & $1.32(0.78,2.21)$ & $0.93(0.56,1.53)$ & $1.11(0.76,1.62)$ & $1.36(0.88,2.09)$ \\
\hline \multicolumn{7}{|l|}{ Ht4 (TGT) } \\
\hline \multirow[t]{2}{*}{ Dominant } & $\mathrm{p}$ value & 0.03 & 0.3 & 0.8 & 0.4 & 0.4 \\
\hline & OR (95\% CI) & $2.14(1.06,4.28)$ & $0.71(0.35,1.43)$ & $0.94(0.5,1.74)$ & $1.18(0.74,1.88)$ & $0.81(0.46,1.41)$ \\
\hline \multirow[t]{2}{*}{ Recessive $^{\mathrm{a}}$} & $\mathrm{p}$ value & 0.9 & 0.9 & 0.9 & 0.8 & 0.9 \\
\hline & OR $(95 \% \mathrm{CI})$ & 0 & 0 & 0 & $1.41(0.08,23.57)$ & 0 \\
\hline \multirow[t]{2}{*}{ Codominant $^{\mathrm{a}}$} & $\mathrm{p}$ value & 0.9 & 0.4 & 0.1 & 0.4 & 0.3 \\
\hline & OR $(95 \% \mathrm{CI})$ & $1.03(0.34,3.09)$ & $1.4(0.55,3.55)$ & $1.84(0.81,4.21)$ & $0.77(0.39,1.51)$ & $0.68(0.33,1.41)$ \\
\hline \multicolumn{7}{|l|}{ Ht6 (TA) } \\
\hline Dominant & $\mathrm{p}$ value & 0.003 & 0.5 & 0.6 & 0.4 & 0.9 \\
\hline & OR $(95 \% \mathrm{CI})$ & $0.29(0.12,0.67)$ & $0.78(0.39,1.57)$ & $0.86(0.45,1.67)$ & $0.82(0.49,1.36)$ & $0.98(0.53,1.79)$ \\
\hline Recessive & $\mathrm{p}$ value & 0.05 & 0.5 & 0.8 & 0.2 & 0.7 \\
\hline & OR $(95 \% \mathrm{CI})$ & $0.28(0.083,1)$ & $1.22(0.61,2.43)$ & $1.06(0.55,2.04)$ & $0.73(0.44,1.21)$ & $1.07(0.61,1.91)$ \\
\hline Codominant & $\mathrm{p}$ value & 0.002 & 0.9 & 0.8 & 0.2 & 0.8 \\
\hline & OR $(95 \% \mathrm{CI})$ & $0.39(0.21,0.72)$ & $0.98(0.64,1.52)$ & $0.97(0.65,1.45)$ & $0.82(0.61,1.12)$ & $1.02(0.71,1.46)$ \\
\hline HT7 (TG) & & & & & & \\
\hline Dominant & $\mathrm{p}$ value & 0.01 & 0.6 & 0.6 & 0.8 & 0.2 \\
\hline & OR $(95 \% \mathrm{CI})$ & $2.88(1.24,6.68)$ & $0.85(0.44,1.62)$ & $1.14(0.63,2.07)$ & $1.04(0.66,1.62)$ & $0.72(0.43,1.22)$ \\
\hline Recessive & $\mathrm{p}$ value & 0.03 & 0.2 & 0.8 & 0.1 & 0.2 \\
\hline & OR $(95 \% \mathrm{CI})$ & $0.38(0.05,2.99)$ & $0.42(0.09,1.86)$ & $1.11(0.39,3.14)$ & $1.76(0.82,3.77)$ & $0.55(0.2,1.48)$ \\
\hline Codominant & $\mathrm{p}$ value & 0.1 & 0.3 & 0.7 & 0.4 & 0.1 \\
\hline & OR $(95 \% \mathrm{CI})$ & $1.57(0.88,2.81)$ & $0.79(0.47,1.32)$ & $1.1(0.71,1.72)$ & $1.14(0.81,1.59)$ & $0.74(0.49,1.11)$ \\
\hline
\end{tabular}


Table 6 (continued)

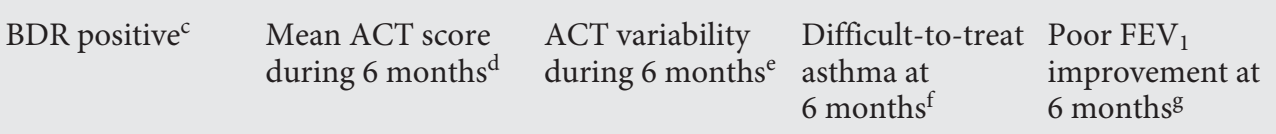

\begin{tabular}{cllllll} 
Ht8 (CA) & & & & & \\
Dominant & p value & 0.06 & 0.7 & 0.3 & 0.7 & 0.1 \\
& OR $(95 \% \mathrm{CI})$ & $2.13(0.95,4.78)$ & $0.91(0.48,1.73)$ & $0.73(0.4,1.33)$ & $1.08(0.69,1.7)$ & $1.46(0.87,2.46)$ \\
\hline Recessive & p value & 0.2 & 0.002 & 0.1 & 0.4 & 0.5 \\
& OR $(95 \% \mathrm{CI})$ & $2.39(0.58,9.78)$ & $5.78(1.92,17.45)$ & $2.31(0.74,7.23)$ & $1.54(0.53,4.44)$ & $1.38(0.44,4.32)$ \\
\hline Codominant & p value & 0.04 & 0.2 & 0.7 & 0.5 & 0.2 \\
& OR $(95 \% \mathrm{CI})$ & $1.87(1.01,3.48)$ & $1.32(0.78,2.21)$ & $0.92(0.56,1.52)$ & $1.12(0.76,1.64)$ & $1.36(0.88,2.09)$ \\
\hline
\end{tabular}

n.a. $=$ Not assessed. ${ }^{a}$ Models of Ht (dominant: Ht/Ht + Ht/others vs. others/others, recessive: Ht/Ht vs. Ht/others + others/others, codominant: $\mathrm{Ht} / \mathrm{Ht}$ vs. Ht/others vs. others/others). ${ }^{\mathrm{b}} \mathrm{p}$ value from multiple logistic regression analysis after adjusting for age, gender and BMI. ${ }^{\mathrm{C}}$ Control (reference): negative bronchodilator response (BDR); case: positive BDR. ${ }^{\mathrm{d}}$ Control (reference): the average of ACT scores at 3 and 6 months $>19$; case: $\leq 19 .{ }^{\mathrm{e}}$ Control (reference): the difference between ACT score at 3 and 6 months $\geq 4$; case: $<4$. ${ }^{\mathrm{f}}$ Control (reference): patients who achieved control status at step 4 (reliever $+\geq 2$ controllers) treatment at 6 months after enrolment; case: patients

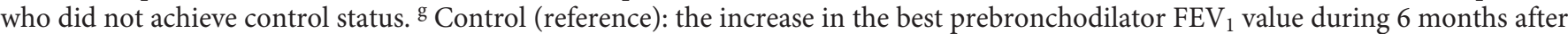
enrolment $\geq 200 \mathrm{ml}$ and $12 \%$ predicted; case: $<200 \mathrm{ml}$ and $12 \%$ predicted.

airway tissues also demonstrated a TAS2R-mediated bronchodilator effect. Based on these data, TAS2R agonists are currently being considered as a new target for treatment of severe asthma.

To date, several studies reported the association between genetic variation in the TAS2R gene and specific diseases. A coding SNP, $r s 846664$ in the TAS2R16 gene, is believed to exert an influence on the risk of alcohol dependence, especially in African Americans, and another research also noted a significant association between variation in the TAS2R13 gene and alcohol consumption in patients with head and neck cancer [40-42]. In contrast, Campa et al. [43] reported that the common polymorphism of the TAS2R14 gene was not a major risk factor in the development of colorectal cancer. However, to the best of our knowledge, this is the first study examining the relationship between genetic variation in bitter taste receptors and respiratory disease.

In the current study, the genetic variations $-815 \mathrm{~T}>\mathrm{C}$, $-1267 \mathrm{~A}>\mathrm{G}$ and $-1897 \mathrm{~T}>\mathrm{C}$ in TAS2R14 were associated with a positive BDR, i.e., with airway reversibility. Moreover, there was a significant association between some haplotypes with minor alleles at $-815 \mathrm{~T}>\mathrm{C}$ and $-1267 \mathrm{~A}>\mathrm{G}[\mathrm{Ht} 3$ (CAT), Ht4 (TGT), Ht7 (TG) and Ht8 (CA)] and a positive BDR. By $>$ T, SNPs [Ht2 (TAC), Ht6 (TA)] demonstrated an inverse correlation with airway reversibility. Indeed, we consider that asthma medication or control state at enrolment might not affect the response to the BDR test because bronchodilators were stopped at least 3 days before we per- formed the test. A possible explanation of these results is that TAS2R- and $\beta_{2} \mathrm{AR}$-induced bronchodilation might be sharing the mechanism of action, at least in part. Bronchodilation by TAS2R agonists has initially been supposed to be mediated by $\mathrm{K}_{\mathrm{Ca}}$ channels, and later, Zhang et al. [14] suggested that TAS2R agonists induced relaxation in contracted airway smooth muscle cells by inhibiting L-type voltage-dependent calcium channels via $G \beta \gamma$ signaling pathways $[9,14]$. However, several discrepancies were reported in these results $[12,13,44]$. Recently, Tan and Sanderson [46] have demonstrated that TAS2R agonists reversed bronchoconstriction by reducing the frequency of calcium oscillations and calcium sensitivity using mouse lung tissues. A similar mechanism has been reported in $\beta_{2}$ AR-induced bronchodilation as shown in previous research $[2,45,46]$. Taken together, the results in the current study implied that genetic variation in the TAS2R gene affects the airway reversibility by varying the degree of calcium oscillation and sensitivity of lung tissues. However, the crosstalk between $\beta_{2} \mathrm{AR}$ and TAS2R remains poorly known, thus further study in this area is needed.

Interestingly, the $\mathrm{C}$ allele in $-815 \mathrm{~T}>\mathrm{C}$ as an individual $\mathrm{SNP}$, and haplotypes including the same allele [Ht2 (TAC) and Ht6 (TA)], were associated with a low mean ACT score during the 6-month period following enrolment, indicating that this genetic variation was associated with poorly controlled asthma as well as with a positive $\mathrm{BDR}$ response to a short-acting $\beta_{2}$-agonist. Indeed, variability of airflow limitation is a principal characteristic of 
asthma [47], and several studies have demonstrated that BDR correlates with airway inflammation leading to poor control of asthma [47-50]. Therefore, we can speculate that polymorphisms in TAS2R might affect therapeutic outcomes of asthma treatment by affecting airway reversibility, because the subjects involved in this study received optimal asthma treatment, including inhaled corticosteroids and bronchodilators, during the follow-up period.

There are some limitations in this study. First, we used a conventional gene-based analysis and a tagging approach, which is currently accepted as an ideal model for gene association studies [51]. However, the current study had a relatively small sample size, and we acknowledge that this point may act as a limitation. Nevertheless, previous studies have indicated that a sample size of 500 individuals is sufficient to discover causative polymorphisms [52]. Second, to assess the asthma control status of study subjects, we used an average ACT score at 3 and 6 months. Therefore, the current study did not fully reflect the status of the patients who changed from one group to the other (e.g. from the low ACT group at 3 months to the high ACT group at 6 months) during 3 months. To compensate for this, we have included another variable, i.e. ACT variability. However, this variable also has a limit for tracing the changes in each individual. Further research with an increased sample size, including the trace of some variables which have a high variability, such as the ACT score, is needed to achieve greater statistical power. In addition, replication of our results in another dataset is also necessary.

In summary, the minor alleles in the $-815 \mathrm{~T}>\mathrm{C}$, $-1267 \mathrm{~A}>\mathrm{G}$ and $-1897 \mathrm{~T}>\mathrm{C}$ SNPs in TAS2R14, and haplotypes including these SNPs, were associated with airway reversibility. In particular, the minor allele in $-815 \mathrm{~T}>\mathrm{C}$ has a strong association with poor asthma control. Our findings suggest that genetic variations in bitter taste receptors may be valuable genetic markers to predict therapeutic responses and outcome in asthma patients. A large population-based prospective study and a functional study are needed to fully understand the importance of bitter taste receptors in asthma.

\section{Financial Disclosure and Conflicts of Interest}

This study was supported by a grant from the Korea Healthcare Technology R and D project, Ministry of Health and Welfare, Republic of Korea (HI14C1971). There are no potential conflicts of interest related to this article or the research described.

\section{References}

1 Perez JF, Sanderson MJ: The frequency of calcium oscillations induced by $5-\mathrm{HT}, \mathrm{ACH}$, and $\mathrm{KCl}$ determine the contraction of smooth muscle cells of intrapulmonary bronchioles. J Gen Physiol 2005; 125:535-553.

2 Delmotte P, Sanderson MJ: Effects of formoterol on contraction and $\mathrm{Ca}^{2+}$ signaling of mouse airway smooth muscle cells. Am J Respir Cell Mol Biol 2010;42:373-381.

-3 Bateman ED, Hurd SS, Barnes PJ, Bousquet J, Drazen JM, FitzGerald M, Gibson P, Ohta K, O'Byrne P, Pedersen SE, Pizzichini E, Sullivan SD, Wenzel SE, Zar HJ: Global strategy for asthma management and prevention: GINA executive summary. Eur Respir J 2008;31:143-178.

4 Barnes PJ: Severe asthma: advances in current management and future therapy. J Allergy Clin Immunol 2012;129:48-59.

5 Weiss KB, Sullivan SD: The health economics of asthma and rhinitis. I. Assessing the economic impact. J Allergy Clin Immunol 2001; 107:3-8.

-6 Himes BE, Jiang X, Hu R, Wu AC, Lasky-Su JA, Klanderman BJ, Ziniti J, Senter-Sylvia J, Lima JJ, Irvin CG, Peters SP, Meyers DA, Bleecker ER, Kubo M, Tamari M, Nakamura Y, Szefler SJ, Lemanske RF Jr, Zeiger RS, Strunk RC, Martinez FD, Hanrahan JP, Kop- pelman GH, Postma DS, Nieuwenhuis MA, Vonk JM, Panettieri RA Jr, Markezich A, Israel E, Carey VJ, Tantisira KG, Litonjua AA, Lu Q, Weiss ST: Genome-wide association analysis in asthma subjects identifies SPATS2L as a novel bronchodilator response gene. PLoS Genet 2012;8:e1002824.

7 Grainge CL, Lau LC, Ward JA, Dulay V, Lahiff G, Wilson S, Holgate S, Davies DE, Howarth PH: Effect of bronchoconstriction on airway remodeling in asthma. N Engl J Med 2011;364:2006-2015.

8 Deshpande DA, Penn RB: Targeting G protein-coupled receptor signaling in asthma. Cell Signal 2006;18:2105-2120.

$\checkmark 9$ Deshpande DA, Wang WC, McIlmoyle EL, Robinett KS, Schillinger RM, An SS, Sham JS, Liggett SB: Bitter taste receptors on airway smooth muscle bronchodilate by localized calcium signaling and reverse obstruction. Nat Med 2010;16:1299-1304.

10 Shah AS, Ben-Shahar Y, Moninger TO, Kline JN, Welsh MJ: Motile cilia of human airway epithelia are chemosensory. Science 2009; 325:1131-1134

11 Pulkkinen V, Manson ML, Safholm J, Adner M, Dahlen SE: The bitter taste receptor (TAS2R) agonists denatonium and chloro- quine display distinct patterns of relaxation of the guinea pig trachea. Am J Physiol Lung Cell Mol Physiol 2012;303:L956-L966.

12 Belvisi MG, Dale N, Birrell MA, Canning BJ: Bronchodilator activity of bitter tastants in human tissue. Nat Med 2011;17:776; author reply 776-778.

13 Zhang CH, Chen C, Lifshitz LM, Fogarty KE, Zhu MS, ZhuGe R: Activation of BK channels may not be required for bitter tastant-induced bronchodilation. Nat Med 2012;18:648-650; author reply 650-651.

14 Zhang CH, Lifshitz LM, Uy KF, Ikebe M, Fogarty KE, ZhuGe R: The cellular and molecular basis of bitter tastant-induced bronchodilation. PLoS Biol 2013;11:e1001501.

15 Grassin-Delyle S, Abrial C, Fayad-Kobeissi S, Brollo M, Faisy C, Alvarez JC, Naline E, Devillier P: The expression and relaxant effect of bitter taste receptors in human bronchi. Respir Res 2013;14:134.

16 Barnes PJ: New drugs for asthma. Nat Rev Drug Discov 2004;3:831-844.

17 Salpeter SR, Buckley NS, Ormiston TM, Salpeter EE: Meta-analysis: effect of long-acting beta-agonists on severe asthma exacerbations and asthma-related deaths. Ann Intern Med 2006;144:904-912.
Bitter Taste Receptor Gene

Polymorphisms in Asthma 
-18 Sin DD, Man J, Sharpe H, Gan WQ, Man SF: Pharmacological management to reduce exacerbations in adults with asthma: a systematic review and meta-analysis. JAMA 2004; 292:367-376.

19 Donohue JF: Therapeutic responses in asthma and COPD. Bronchodilators. Chest 2004; 126:125S-137S; discussion 159S-161S.

20 Hall IP, Wheatley A, Wilding P, Liggett SB: Association of Glu 27 beta 2-adrenoceptor polymorphism with lower airway reactivity in asthmatic subjects. Lancet 1995;345:12131214.

21 Tan S, Hall IP, Dewar J, Dow E, Lipworth B: Association between beta 2-adrenoceptor polymorphism and susceptibility to bronchodilator desensitisation in moderately severe stable asthmatics. Lancet 1997;350:995-999.

22 Hancox RJ, Sears MR, Taylor DR: Polymorphism of the beta2-adrenoceptor and the response to long-term beta2-agonist therapy in asthma. Eur Respir J 1998;11:589-593.

-23 Ohe M, Munakata M, Hizawa N, Itoh A, Doi I, Yamaguchi E, Homma Y, Kawakami Y: Beta 2 adrenergic receptor gene restriction fragment length polymorphism and bronchial asthma. Thorax 1995;50:353-359.

24 Israel E, Chinchilli VM, Ford JG, Boushey HA, Cherniack R, Craig TJ, Deykin A, Fagan JK, Fahy JV, Fish J, Kraft M, Kunselman SJ, Lazarus SC, Lemanske RF Jr, Liggett SB, Martin RJ, Mitra N, Peters SP, Silverman E, Sorkness CA, Szefler SJ, Wechsler ME, Weiss ST, Drazen JM: Use of regularly scheduled albuterol treatment in asthma: genotype-stratified, randomised, placebocontrolled cross-over trial. Lancet 2004;364: 1505-1512.

-25 Israel E, Drazen JM, Liggett SB, Boushey HA, Cherniack RM, Chinchilli VM, Cooper DM, Fahy JV, Fish JE, Ford JG, Kraft M, Kunselman S, Lazarus SC, Lemanske RF, Martin RJ, McLean DE, Peters SP, Silverman EK, Sorkness CA, Szefler SJ, Weiss ST, Yandava CN: The effect of polymorphisms of the beta(2)adrenergic receptor on the response to regular use of albuterol in asthma. Am J Respir Crit Care Med 2000;162:75-80.

26 Kim TB, Park CS, Bae YJ, Cho YS, Moon HB: Factors associated with severity and exacerbation of asthma: a baseline analysis of the cohort for reality and evolution of adult asthma in Korea (COREA). Ann Allergy Asthma Immunol 2009;103:311-317.

27 Kim TB, Jang AS, Kwon HS, Park JS, Chang YS, Cho SH, Choi BW, Park JW, Nam DH, Yoon HJ, Cho YJ, Moon HB, Cho YS, Park CS: Identification of asthma clusters in two independent Korean adult asthma cohorts. Eur Respir J 2013;41:1308-1314.

-28 Pellegrino R, Viegi G, Brusasco V, Crapo RO, Burgos F, Casaburi R, Coates A, van der Grinten CP, Gustafsson P, Hankinson J, Jensen R, Johnson DC, MacIntyre N, McKay R, Miller MR, Navajas D, Pedersen OF, Wanger $\mathrm{J}$ : Interpretative strategies for lung function tests. Eur Respir J 2005;26:948-968.
29 Thomas M, Kay S, Pike J, Williams A, Rosenzweig JRC, Hillyer EV, Price D: The Asthma Control Test ${ }^{\mathrm{TM}}$ (ACT) as a predictor of GINA guideline-defined asthma control: analysis of a multinational cross-sectional survey. Prim Care Respir J 2009;18:41-49.

30 Schatz M, Sorkness CA, Li JT, Marcus P, Murray JJ, Nathan RA, Kosinski M, Pendergraft TB, Jhingran P: Asthma Control Test: reliability, validity, and responsiveness in patients not previously followed by asthma specialists. J Allergy Clin Immunol 2006;117:549-556.

31 Korn S, Both J, Jung M, Hubner M, Taube C, Buhl R: Prospective evaluation of current asthma control using ACQ and ACT compared with GINA criteria. Ann Allergy Asthma Immunol 2011;107:474-479.

- 32 Ko FW, Hui DS, Leung TF, Chu HY, Wong GW, Tung AH, Ngai JC, Ng SS, Lai CK: Evaluation of the asthma control test: a reliable determinant of disease stability and a predictor of future exacerbations. Respirology 2012; 17:370-378.

33 Hofer D, Drenckhahn D: Identification of the taste cell G-protein, alpha-gustducin, in brush cells of the rat pancreatic duct system. Histochem Cell Biol 1998;110:303-309.

34 Hofer D, Puschel B, Drenckhahn D: Taste receptor-like cells in the rat gut identified by expression of alpha-gustducin. Proc Natl Acad Sci USA 1996;93:6631-6634.

35 Wu SV, Rozengurt N, Yang M, Young SH, Sinnett-Smith J, Rozengurt E: Expression of bitter taste receptors of the T2R family in the gastrointestinal tract and enteroendocrine STC-1 cells. Proc Natl Acad Sci USA 2002;99: 2392-2397.

36 Sternini C: Taste receptors in the gastrointestinal tract. IV. Functional implications of bitter taste receptors in gastrointestinal chemosensing. Am J Physiol Gastrointest Liver Physiol 2007;292:G457-G461.

37 Kinnamon SC: Taste receptor signalling from tongues to lungs. Acta Physiol (Oxf) 2012;204:158-168.

38 Finger TE, Bottger B, Hansen A, Anderson KT, Alimohammadi H, Silver WL: Solitary chemoreceptor cells in the nasal cavity serve as sentinels of respiration. Proc Natl Acad Sci USA 2003;100:8981-8986.

- 39 Einstein R, Jordan H, Zhou W, Brenner M, Moses EG, Liggett SB: Alternative splicing of the $G$ protein-coupled receptor superfamily in human airway smooth muscle diversifies the complement of receptors. Proc Natl Acad Sci USA 2008; 105:5230-5235.

40 Dotson CD, Wallace MR, Bartoshuk LM, Logan HL: Variation in the gene TAS2R13 is associated with differences in alcohol consumption in patients with head and neck cancer. Chem Senses 2012;37:737-744.

41 Hinrichs AL, Wang JC, Bufe B, Kwon JM, Budde J, Allen R, Bertelsen S, Evans W, Dick D, Rice J, Foroud T, Nurnberger J, Tischfield JA, Kuperman S, Crowe R, Hesselbrock V, Schuckit M, Almasy L, Porjesz B, Edenberg HJ, Begleiter H, Meyerhof W, Bierut LJ, Goate
AM: Functional variant in a bitter-taste receptor (hTAS2R16) influences risk of alcohol dependence. Am J Hum Genet 2006;78:103-111.

42 Mangold JE, Payne TJ, Ma JZ, Chen G, Li MD: Bitter taste receptor gene polymorphisms are an important factor in the development of nicotine dependence in African Americans. J Med Genet 2008;45:578-582.

43 Campa D, Vodicka P, Pardini B, Naccarati A, Carrai M, Vodickova L, Novotny J, Hemminki K, Forsti A, Barale R, Canzian F: A genewide investigation on polymorphisms in the taste receptor 2R14 (TAS2R14) and susceptibility to colorectal cancer. BMC Med Genet 2010;11:88.

-44 Sausbier M, Zhou XB, Beier C, Sausbier U, Wolpers D, Maget S, Martin C, Dietrich A, Ressmeyer AR, Renz H, Schlossmann J, Hofmann F, Neuhuber W, Gudermann T, Uhlig S, Korth M, Ruth P: Reduced rather than enhanced cholinergic airway constriction in mice with ablation of the large conductance $\mathrm{Ca}^{2+}$-activated $\mathrm{K}^{+}$channel. FASEB J 2007;21: 812-822.

45 Oguma T, Kume H, Ito S, Takeda N, Honjo H, Kodama I, Shimokata K, Kamiya K: Involvement of reduced sensitivity to $\mathrm{Ca}$ in beta-adrenergic action on airway smooth muscle. Clin Exp Allergy 2006;36:183-191.

-46 Tan X, Sanderson MJ: Bitter tasting compounds dilate airways by inhibiting airway smooth muscle calcium oscillations and calcium sensitivity. Br J Pharmacol 2014;171: 646-662.

47 Koga T, Kamimura T, Oshita Y, Narita Y, Mukaino T, Nishimura M, Mizoguchi Y, Aizawa H: Determinants of bronchodilator responsiveness in patients with controlled asthma. J Asthma 2006;43:71-74.

-48 Kainu A, Lindqvist A, Sarna S, Lundbäck B, Sovijärvi A: FEV1 response to bronchodilation in an adult urban population. Chest 2008; 134:387-393

49 Moore WC, Bleecker ER, Curran-Everett D, Erzurum SC, Ameredes BT, Bacharier L, Calhoun WJ, Castro M, Chung KF, Clark MP, Dweik RA, Fitzpatrick AM, Gaston B, Hew M, Hussain I, Jarjour NN, Israel E, Levy BD, Murphy JR, Peters SP, Teague WG, Meyers DA, Busse WW, Wenzel SE: Characterization of the severe asthma phenotype by the $\mathrm{Na}$ tional Heart, Lung, and Blood Institute's Severe Asthma Research Program. J Allergy Clin Immunol 2007;119:405-413.

50 Jones SL, Kittelson J, Cowan JO, Flannery EM, Hancox RJ, McLachlan CR, Taylor DR: The predictive value of exhaled nitric oxide measurements in assessing changes in asthma control. Am J Respir Crit Care Med 2001;164: 738-743

51 Neale BM, Sham PC: The future of association studies: gene-based analysis and replication. Am J Hum Genet 2004;75:353-362.

52 Long $\mathrm{AD}$, Langley $\mathrm{CH}$ : The power of association studies to detect the contribution of candidate genetic loci to variation in complex traits. Genome Res 1999;9:720-731. 